\title{
Characterization and Antibacterial Activity of Synthesized Silver and Iron Nanoparticles using Aloe vera
}

\author{
Yadav JP*, Kumar S, Budhwar L, Yadav A and Yadav M
}

Department of Genetics, M. D. University, Rohtak-124001, Haryana, India

\begin{abstract}
The main aim of this study was to evaluate the comparative antibacterial potential of silver and Iron nanoparticles synthesized from aqueous plant extracts of Aloe vera. The synthesized nanoparticles were characterzed by UV-VIS spectroscopy, Fourier Transform Infra-Red spectroscopy and Transmission Electron Microscopy. The antibacterial activity of synthesized silver and iron nanoparticles was compared by agar well diffussion method and minimum inhibitory concentration was also calculated. The zone of inhibition varied in range of 9 to $18 \mathrm{~mm}$ for silver nanoparticales and 10 to17 $\mathrm{mm}$ for iron nanoparticles. The maximum zone of inhibition for silver nanoparticles was $18 \mathrm{~mm}$ against Proteus mirabilis. The maximum zone of inhibition for iron nanoparticles was $17 \mathrm{~mm}$ against Klebsiella pneumonia. MICs of silver nanoparticles were found to be in a range from 195 to $780 \mu \mathrm{g} / \mathrm{ml}$ and that of iron was 390 to $1560 \mu \mathrm{g} / \mathrm{ml}$ against tested microbes. The synthesized silver nanoparticles of aqueous Aloe vera extracts have shown good antibacterial efficacy as compared to iron nanoparticles and may prove to be better antibacterial agent against wide range of microbes.
\end{abstract}

Keywords: Aloe vera; Antibacterial activity; Nanoparticle; Characterization; Inhibition zone

\section{Introduction}

Plants are rich sources of various medicinally important substances and they explore the huge diversity in therapeutic and clinical aspects of the society from ancient times. Medicinal plants are a source of many potent and powerful drugs and used all over the world for the treatment of several chronic diseases [1]. Due to having wide biological and medicinal properties, high safety margins and lesser costs, there is a great demand of herbal medicines in both developed and developing countries as a source of primary health care [2,3]. Reporting more than 2000 species of medicinally important plants with high potential abilities for use in different traditional medicine systems, India has a rich culture of medicinal herbs and spices but chemically and pharmacologically studies for their medicinal potential are very few in literature $[4,5]$

Aloe vera is a shrubby, perennial succulent plant of Liliaceae family having turgid leaves joined at the stem in a rosette pattern. Plant is also characterized by stemless large, thick, fleshy leaves having a sharp apex and a spiny margin [6]. Aloe vera has been traditionally used for a variety of medicinal purposes and significantly involved in indigenous medicine system of India. It has gained high importance for its diverse therapeutic properties. Aloe vera contains over hundreds of nutrients and active compounds. Different phytoconstituents as; vitamins, enzymes, minerals, sugars, lignin, anthraquinones, saponins, salicylic acid and amino acids are responsible for their medicinal and therapeutic properties [7]. Aloe vera has been shown to have anti inflammatory activity, immuno stimulatory activity and cell growth stimulatory activity [8-10]. Activity against a variety of infectious agents in terms of antiviral, antifungal and antibacterial has been also reported [11-13]. Since early times, Aloe vera gel has been used for the treatment of several skin cuts and burn abnormalities too [14].

Nanotechnology and their derived products are unique not only in their treatment and methodology but also in particle size, physical, chemical and biochemical properties [15]. An important aspect of nanotechnology is to design the experimental methods for the synthesis of nanoparticles with huge dispersity at the level of chemical composition, size, shape and utility $[16,17]$ Nanoparticles are ultrafine particles with their size ranging from 1-100 nm. The biosynthesis of noble metal nanoparticles (silver, gold, platinum, palladium etc.) has received considerable attention due to the growing need to develop environmentally friendly technologies in material synthesis [18].
Nanoparticles attract more researchers for the future developments in the area of medicine, healthcare and agriculture due to their diverse remarkable and captivating range of biological applications [19]. These materials having zero to three dimensional characteristics and can be used as thin films or surface coatings, nanowires, carbon nanotubes, inorganic nanotubes, biopolymers, nanoribbons, fullerenes, dendrimers and quantum dots [20-23] etc.

In present study, silver and iron nanoparticles of Aloe vera leaf extracts were synthesized and their antibacterial activities were performed against 9 reference bacterial strains. This study is the first attempt to evaluate comparative antibacterial potential of silver and iron nanoparticles synthesized from Aloe vera.

\section{Materials and Methods}

\section{Collection of plant material}

Healthy leaves of Aloe vera were collected from Rohtak (India). The plant material was identified and authenticated by comparing the herbarium specimen available in Department of Genetics, M. D. University, Rohtak (India). Herbarium specimen number is MDU6803. Tissues were placed in sterile plastic bags and brought in an ice box, sealed properly. All samples were brought to the laboratory and processed further.

\section{Preparations of leaf extract (reducing agent)}

Leaf extract was prepared by taking $20 \mathrm{gm}$ of leaves. Leaves were washed thoroughly with double distilled water, dried at room temperature and cut into fine pieces. Fine pieces are boiled in $100 \mathrm{ml}$ double distilled water for 20 minutes at $60^{\circ} \mathrm{C}$ in a glass beaker. After boiling the extract was filtered using Whatman No.1.

*Corresponding author: Yadav JP, Department of Genetics, M. D. University, Rohtak-124001, Haryana, India, Tel: +91-9416474640; E-mail: yadav1964@rediffmail.com

Received May 19, 2016; Accepted June 14, 2016; Published June 21, 2016

Citation: Yadav JP, Kumar S, Budhwar L, Yadav A, Yadav M (2016) Characterization and Antibacterial Activity of Synthesized Silver and Iron Nanoparticles using Aloe vera. J Nanomed Nanotechnol 7: 384. doi:10.4172/2157-7439.1000384

Copyright: ( 2016 Yadav JP, et al. This is an open-access article distributed under the terms of the Creative Commons Attribution License, which permits unrestricted use, distribution, and reproduction in any medium, provided the original author and source are credited. 


\section{Preparation of precursors}

Precursors for both silver and iron NPs $\left(\mathrm{AgNO}_{3}\right.$ and $\mathrm{FeCl}_{3}$ respectively) were purchased from Sigma Aldrich chemicals, India and prepared freshly. Precursor for preparing silver nanoparticle was $0.001 \mathrm{M}$ of silver nitrate using double distilled Water. Precursor for preparing iron nanoparticle was $0.001 \mathrm{M}$ of ferric Chloride using double distilled Water.

\section{Synthesis of nanoparticles by green synthesis process}

$2 \mathrm{ml}$ stock solution of leaf extract was slowly added into $20 \mathrm{ml}$ of $1 \mathrm{mM}$ solution of silver nitrate under continuous stirring for $20 \mathrm{~min}$. The solution was incubated for $24 \mathrm{hrs}$ at room temperature. Colourless solution changed into pale yellow colour initially and after $24 \mathrm{hrs}$ colour changed from pale yellow to reddish brown which indicates formation of silver nanoparticles. For the synthesis of iron Nanoparticles both the precursor and the reducing agent were mixed in a clean sterilized flask in 1:1 proportion. Then the solutions were centrifuged at $12,000 \mathrm{rpm}$ for $15 \mathrm{~min}$, consequently dispersed in double distilled water to remove any heavy-handed biological materials with constant stirring at 50$60^{\circ} \mathrm{C}$. Sedmented NPs were given three washing with double distilled water at 12,000 rpm for $15 \mathrm{~min}$. Finally NPs were lypholized to obtain a fine powder.

\section{Particles characterization}

UV-Vis spectroscopy: Ultraviolet-visible spectroscopy (UV-Vis) refers to absorption spectroscopy in the UV-Visible spectral region. The NPs were characterized in a Shimadzu UV-VIS Spectrophotometer. The scanning range for the samples was $300-700 \mathrm{~nm}$. The double distilled water used as a blank reference.

Fourier transform infra-red spectroscopy (FTIR): The nanoparticles were characterized using a Fourier Transform Infrared Spectrophotometer (FTIR 8400S, Shimadzu, Tokyo, Japan). 2 milligrams of the sample was mixed with $100 \mathrm{mg}$ potassium bromide $(\mathrm{KBr})$. Then, compressed to prepare a salt disc approximately $3 \mathrm{~mm}$ in diameter and the disc were immediately kept in the sample holder. FTIR spectra were recorded in the absorption range between 400 and $4000 \mathrm{~cm}^{\boxplus 1}$.

Transmission electron microscopy (TEM): The shape and sizes of synthesized Silver and Iron nanoparticles were determined by transmission electron microscopy. A drop ( $2 \mathrm{ul}$ ) of water that dissolved synthesized nanoparticles was placed on a copper grid. The images were obtained with a Tecnai, Twin $200 \mathrm{KV}$ (FEI, Netherlands) at a bias voltage of $200 \mathrm{kV}$ used to analyze samples.

\section{Antibacterial activity}

Reference strains: Pathogenic reference ATCC (American Type Culture Collection) strains were used for checking activity. 9 bacterial strains were used for the study. Strains were procured from Post Graduate Institute of Medical Sciences, Rohtak (India). Out of 9 bacterial strains, viz. Shigella flexneri ATCC 12022, Proteus mirabilis ATCC 43071, Salmonella typhi ATCC 13311, Serratia marcescens ATCC 27137, Klebsiella pneumonia ATCC 700603, Escherichia coli ATCC 25922, Pseudomonas aeruginosa ATCC 27853, Enterococcus faecalis ATCC 29212 and Staphylococus aureus ATCC 259323.

Preparation of test samples: To test the antimicrobial activity, nanoparticles were dissolved in $5 \%$ DMSO to make a stock solution of $20 \mathrm{mg} / \mathrm{ml}$. Different dilutions of stock solution $(400,600,800,1000$ $\mu \mathrm{g} / \mathrm{ml}$ ) were used to detect antibacterial activity of the synthesized NPs.
Antibacterial bioassay: Antibacterial activity was checked by agar well diffusion method. Fresh overnight grown culture was used for inoculums preparation. Inoculums were prepared in peptone water and incubated for 2 hours. Turbidity was adjusted equivalent to 0.5 McFarland units (approximately $10^{8} \mathrm{CFU} / \mathrm{ml}$ ). Inoculums were spread over fresh nutrient agar plates with a sterile spreader. 4 wells of $6 \mathrm{~mm}$ diameter were cut with the help of a sterile cutter. Control disc was placed in centre. $40 \mu \mathrm{l}$ solution of different concentrations was added in the wells to study the antibacterial activity against the used bacterial strains. DMSO was used as negative control. $10 \mu \mathrm{g}$ streptomycin (Himedia laboratories Pvt. Ltd, India) discs were used as positive control. Both were purchased from Plates were incubated for 24 hours at $37^{\circ} \mathrm{C}$. Clear zone of inhibition around each well was measured with help of standard ruler HiAntibiotic ZoneScale ${ }^{\mathrm{TM}}-\mathrm{C}$ supplied by HiMedia Laboratories Pvt. Ltd. India. Each experiment was done in triplicates.

Minimum inhibitory concentration [MIC]: MIC is the lowest concentration of an antimicrobial that will inhibit the visible growth of a microorganism after overnight incubation. The MIC values of extracts were determined based on a micro broth dilution method in 96 multi-well micro titer plates developed by Sarkar et al. with slight modifications [24]. $50 \mu \mathrm{l}$ of nutrient broth and $50 \mu \mathrm{l}$ of normal saline were added to each well of plate. A volume of $100 \mu \mathrm{l}$ of test materials in added into the first row of the plate. Serial dilutions were performed such that each well had total $100 \mu$ of the test material in serially descending concentrations. $10 \mu \mathrm{l}$ of resazurin indicator solution (prepared by dissolving a $270 \mathrm{mg}$ tablet in $40 \mathrm{ml}$ of sterile distilled water) was added in each well. Finally $10 \mu \mathrm{l}$ of bacterial suspension concentration of $5 \times 10^{6} \mathrm{CFU} / \mathrm{ml}$ was added to each well. Plate had a column with streptomycin as positive control. The plates were prepared in triplicate and placed in an incubator at $37^{\circ} \mathrm{C}$ for 18 to $24 \mathrm{~h}$. Any colour change from purple to pink indicates growth of microbes. The highest dilution at which no color change occurred was taken as the MIC value of extract and was expressed in $\mathrm{mg} / \mathrm{ml}$.

\section{Statistical analysis}

All values are expressed as Mean \pm standard deviation (SD) of three separate experiments using the computer programme MS Excel.

\section{Results}

\section{Synthesis of nanoparticles by green synthesis process}

Reaction was visible as a colour change from light green to brown within $24 \mathrm{~h}$ of the addition of reaction mixture. Figure 1a-1e shows the difference in colour of extract and synthesized nanoparticles.

\section{Characterization of synthesized nanoparticles}

UV-Vis spectroscopy: Absorption spectra of Ag nanoparticles formed in the reaction media has absorbance maxima at $475 \mathrm{~nm}$. A peak specific for the synthesis of silver nanoparticles was obtained at 420$500 \mathrm{~nm}$ by UV-Visible spectroscope (Figure 2a). Absorption spectra of Fe nanoparticles formed in the reaction media have absorbance maxima at 225 and $400 \mathrm{~nm}$. A peak specific for the synthesis of iron nanoparticles was obtained at $200-430 \mathrm{~nm}$ by UV Visible spectroscope (Figure 2b).

Fourier transform infra-red spectroscopy (FTIR): The FTIR spectrum was used to identify the functional groups of the active components based on the peak value in the region of infrared radiation. Frequency $\left(\mathrm{cm}^{-1}\right)$ as; 3500-3200 (O-H stretch, H-bonded alcohols, phenols), 3300-2500 (O-H stretch carboxylic acids), 3000-2850 (C-H 
Citation: Yadav JP, Kumar S, Budhwar L, Yadav A, Yadav M (2016) Characterization and Antibacterial Activity of Synthesized Silver and Iron Nanoparticles using Aloe vera. J Nanomed Nanotechnol 7: 384. doi:10.4172/2157-7439.1000384

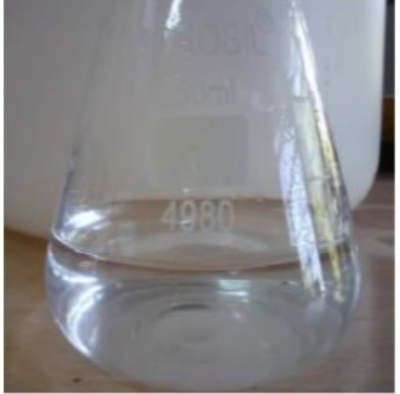

(a)

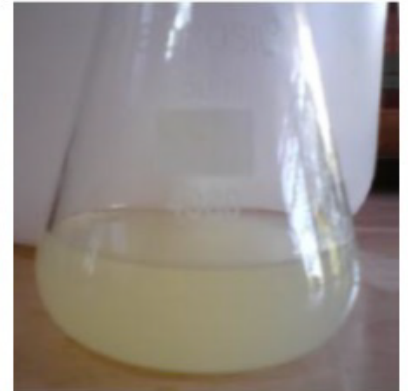

(b)

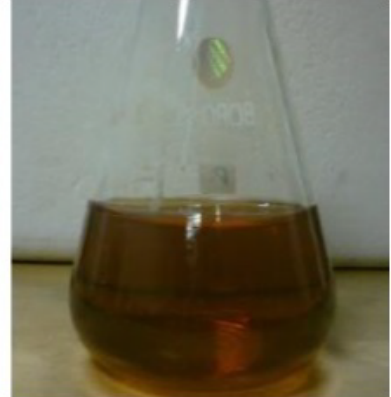

(c)

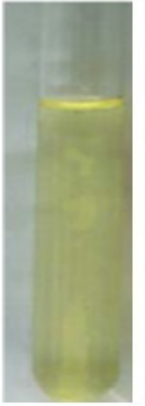

(d)

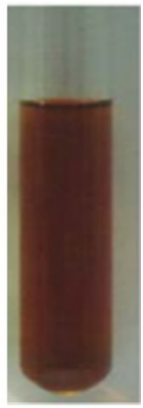

(e)

Figure 1: (a) $0.001 \mathrm{M}\left(\mathrm{AgNo}_{3}\right)$. (b) Aloe vera plant extract. (c) Silver nitrate solution after keeping at incubation in the dark for $24 \mathrm{~h}$. (d) Aloe vera plant extract after 5 min of incubation. (e) $\mathrm{FeCl}_{3}$ solution after keeping at incubation in the dark for $24 \mathrm{~h}$.

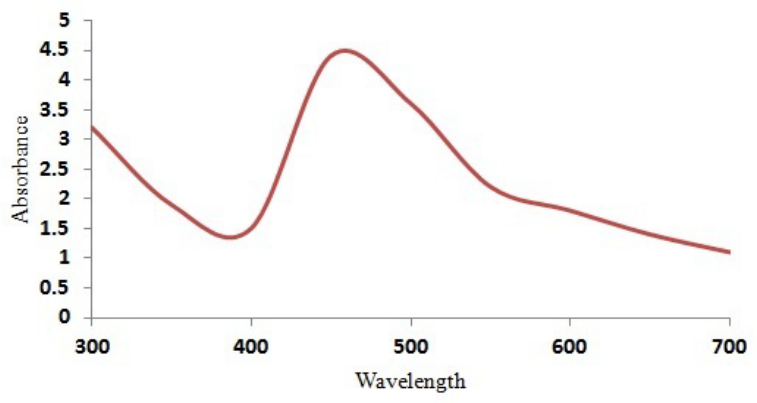

(a)

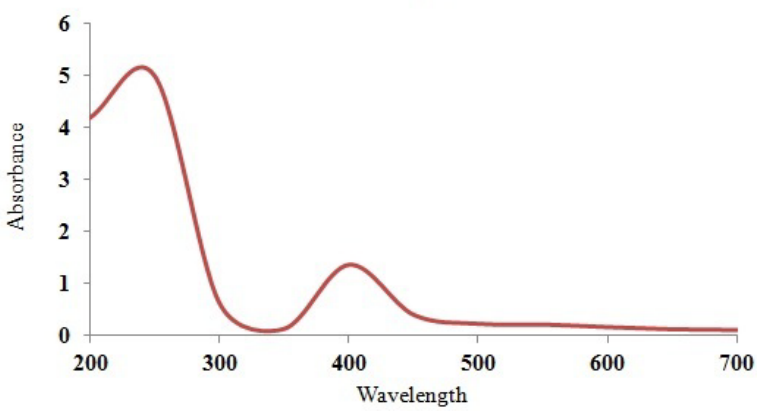

(b)

Figure 2: (a) Absorption spectra of AgNPs formed in the reaction media. (b) Absorption spectra of FeNPs formed in the reaction media.

stretch alkanes), 1600-1585 (C-C stretch (in-ring) aromatics), 15001400 (C-C stretch (in-ring) aromatics), 1390-1350 (C-H rock alkanes), 1360-1290 (N-O symmetric stretch nitro compounds), 1320-1000 (C-O stretch esters, ethers), 1250-1020 (C-N stretch aliphatic amines), 910-665 (N-H wag $1^{\circ}, 2^{\circ}$ amines), 900-675 (C-H “oop"aromatics), 690515 (C-Br stretch alkyl halides) etc. were observed $[25,26]$. Peak values of different compounds present with their frequencies and functional groups are showed in Table 1. Absorption spectra of AgNPs and FeNPs formed from FTIR analysis is depicted in Figure $3 \mathrm{a}$ and $3 \mathrm{~b}$.

Transmission Electron Microscopy (TEM): The TEM image showing silver nanoparticles synthesized using plant extract confirmed the development of spherical silver and iron nanostructures by Aloe vera and showed an average size of $36.61 \pm 4.88 \mathrm{~nm}$ for AgNPs and $34.93 \pm 0.84 \mathrm{~nm}$ for FeNPs (Figure $4 \mathrm{a}$ and $4 \mathrm{~b}$ ) respectively.

\section{Antibacterial activity}

Antibacterial activity of silver nanoparticles: Silver nanoparticles of Aloe vera showed inhibition zones ranging from 9 to $18 \mathrm{~mm}$ against different reference strains. The effect of different concentrations of silver nanoparticles against bacteria is given in Table 2. AgNP showed greater inhibition zone $(18 \mathrm{~mm})$ against Proteus mirabili more than positive control. MIC values for silver NPs against different bacterial strains ranged from 195 to $780 \mu \mathrm{g} / \mathrm{ml}$. Silver NPs showed minimum MIC values against $P$. mirabilis, $S$. flexneri and $S$. aureus strains while maximum against E. coli, K. pneumoniae, $P$. aeruginosa and $S$. typhi strains (Figure 5).

Antibacterial activity of iron nanoparticles: Iron nanoparticles of Aloe vera showed inhibition zones ranging from 10 to $17 \mathrm{~mm}$ against different reference strains. The effect of different concentrations of iron nanoparticles against bacteria has been given in Table 3. The maximum zone of inhibition was $17 \mathrm{~mm}$ against Klebsiella pneumonia. MIC values for iron NPs against different bacterial strains ranged from 390 to 1560 $\mu \mathrm{g} / \mathrm{ml}$. Iron NPs showed minimum MIC values against $P$. mirabilis, $K$. pneumonia, $P$. aeruginosa and $S$. typhi strains and maximum against $S$. flexneri strain (Figure 5).

\section{Discussion}

Nanoparticle synthesis is an emerging area of research in the scientific world. Wide range of applications in different aspects of human life is the reason for the great attraction of researchers towards this field. Green chemistry procedure, probably involving organisms ranging from bacteria to fungi and even plants would benefit the development of clean, nontoxic and environmentally acceptable synthesis and assembly of nanoparticles [27]. Biological organisms use is an alternative to chemical and physical methods for the production of nanoparticles in an eco-friendly manner [28]. Development of resistant strains and antibiotic resistance has been increased in recent years. Some antimicrobial agents are extremely irritant and toxic and the studies on drug resistant bacteria are still limited. Due to the increasing demand of non malign solvents and renewable materials biosynthesis of metallic nanoparticles is receiving significant attention [29,30]. Plant mediated synthesis is actively being practiced by the researchers for its positive advantages like avoidance of maintaining the microbial culture, being time-consuming, and being cost effective as compared to microbes [31]. The various nanoparticles like gold, silver, copper, iron, palladium, zinc, quantum dots etc. are synthesized 
Citation: Yadav JP, Kumar S, Budhwar L, Yadav A, Yadav M (2016) Characterization and Antibacterial Activity of Synthesized Silver and Iron Nanoparticles using Aloe vera. J Nanomed Nanotechnol 7: 384. doi:10.4172/2157-7439.1000384

Page 4 of 7

\begin{tabular}{|c|c|c|c|c|}
\hline Frequency $\left(\mathrm{cm}^{-1}\right)$ & Chemical bond & Phytoconstituent present & $\begin{array}{l}\text { Peak observed } \\
\text { (silver NPs) }\end{array}$ & $\begin{array}{l}\text { Peak observed } \\
\text { (iron NPs) }\end{array}$ \\
\hline $3500-3200$ & $\mathrm{O}-\mathrm{H}$ stretch & Alcohols or phenols & 3446 & 3417 \\
\hline $3300-2500$ & $\mathrm{O}-\mathrm{H}$ stretch & Carboxylic acids & 2918,2362 & 2961,2924 \\
\hline $3000-2850$ & C-H stretch & Alkanes & 2849,2734 & 2816,2728 \\
\hline $1600-1585$ & C-C stretch (in-ring) & Aromatics & 1593 & 1591 \\
\hline $1500-1400$ & C-C stretch & Aromatics & 1466, & 1483 \\
\hline $1390-1350$ & C-H rock & Alkanes & 1383 & 1383 \\
\hline $1360-1290$ & $\mathrm{~N}-\mathrm{O}$ symmetric stretch & Nitro Compounds & 1350 & 1350 \\
\hline $1320-1000$ & C-O stretch & Esters, ethers & 1169 & 1018 \\
\hline $1250-1020$ & C-N stretch & Aliphatic amines & 1080 & --- \\
\hline $910-665$ & $\mathrm{~N}-\mathrm{H}$ wag & $1^{\circ}, 2^{\circ}$ amines & 765 & 762 \\
\hline $900-675$ & C-H “oop" & Aromatics & 720 & -- \\
\hline $690-400$ & C-Br stretch & Alkyl halides & 554,453 & 451,434 \\
\hline
\end{tabular}

Table 1: FTIR analysis of synthesized silver and iron nanoparticles.

\begin{tabular}{|c|c|c|c|c|c|c|}
\hline \multirow[b]{2}{*}{ Sr. No. } & \multirow[b]{2}{*}{ Bacterial Strains } & \multicolumn{5}{|c|}{ Zone of inhibition in $\mathrm{mm}$ at different concentrations } \\
\hline & & $\begin{array}{c}\text { Control } \\
\text { (Streptomycin) }\end{array}$ & $\begin{array}{c}16 \\
\mu \mathrm{g} / \mathrm{well}\end{array}$ & $24 \mu \mathrm{g} /$ well & $\begin{array}{c}32 \\
\mu \mathrm{g} / \mathrm{well}\end{array}$ & $40 \mu \mathrm{g} /$ well \\
\hline 1 & Escherichia coli (ATCC 25922) & $18 \pm 0.56$ & $11 \pm 0.44$ & $12 \pm 0.54$ & $13 \pm 0.40$ & $15 \pm 0.13$ \\
\hline 2 & Proteus mirabilis (ATCC 43071) & $16 \pm 0.23$ & $10 \pm 0.27$ & $11 \pm 0.29$ & $13 \pm 0.62$ & $18 \pm 0.42$ \\
\hline 3 & Klebsiella pneumoniae (ATCC 700603) & $16 \pm 0.18$ & $13 \pm 0.40$ & $16 \pm 0.50$ & $18 \pm 0.37$ & $15 \pm 0.19$ \\
\hline 4 & Pseudomonas aeruginosa (ATCC27853) & $15 \pm 0.34$ & $10 \pm 0.61$ & $12 \pm 0.36$ & $13 \pm 0.11$ & $15 \pm 0.72$ \\
\hline 5 & Shigella flexneri (ATCC 12022) & $20 \pm 0.09$ & $09 \pm 0.47$ & $11 \pm 0.17$ & $13 \pm 0.39$ & $18 \pm 0.01$ \\
\hline 6 & Serratia marcescens (ATCC 27137) & $16 \pm 0.57$ & $10 \pm 0.31$ & $12 \pm 0.23$ & $13 \pm 0.76$ & $16 \pm 0.26$ \\
\hline 7 & Salmonella typhi (ATCC 13311) & $16 \pm 0.85$ & $10 \pm 0.03$ & $11 \pm 0.91$ & $13 \pm 0.53$ & $15 \pm 0.08$ \\
\hline 8 & Enterococcus faecalis (ATCC 29212) & $17 \pm 0.23$ & $11 \pm 0.51$ & $12 \pm 0.47$ & $14 \pm 0.72$ & $16 \pm 0.58$ \\
\hline 9 & Staphylococcus aureus (ATCC 259323) & $22 \pm 0.63$ & $10 \pm 0.06$ & $12 \pm 0.22$ & $13 \pm 0.05$ & $17 \pm 0.41$ \\
\hline
\end{tabular}

Table 2: Antibacterial activity of silver nanoparticles against 9 reference bacterial strains.

\begin{tabular}{|c|c|c|c|c|c|c|}
\hline \multirow{2}{*}{ Sr. No. } & Bacterial Strains & \multicolumn{3}{|c|}{ Zone of inhibition in $\mathbf{m m}$ at different concentrations } \\
\cline { 2 - 6 } & & $\begin{array}{c}\text { Control } \\
\text { (Streptomycin) }\end{array}$ & $\begin{array}{c}\mathbf{1 6} \\
\boldsymbol{\mu g} / \mathbf{w e l l}\end{array}$ & $\mathbf{2 4} \boldsymbol{\mu g} / \mathbf{w e l l}$ & $\begin{array}{c}\mathbf{3 2} \\
\boldsymbol{\mu g} / \mathbf{w e l l}\end{array}$ & $\mathbf{4 0} \boldsymbol{\mu g} / \mathbf{w e l l}$ \\
\hline 1 & Escherichia coli (ATCC 25922) & $18 \pm 0.25$ & $10 \pm 0.12$ & $11 \pm 0.77$ & $14 \pm 0.5$ & $15 \pm 0.11$ \\
\hline 2 & Proteus mirabilis (ATCC 43071) & $18 \pm 0.11$ & $11 \pm 0.65$ & $13 \pm 0.45$ & $14 \pm 0.32$ & $16 \pm 0.21$ \\
\hline 3 & Klebsiella pneumoniae (ATCC 700603) & $17 \pm 0.73$ & $11 \pm 0.33$ & $13 \pm 0.50$ & $14 \pm 0.70$ & $17 \pm 0.54$ \\
\hline 4 & Pseudomonas aeruginosa (ATCC27853) & $16 \pm 0.91$ & $12 \pm 0.19$ & $13 \pm 0.63$ & $14 \pm 0.12$ & $16 \pm 0.29$ \\
\hline 5 & Shigella flexneri (ATCC 12022) & $20 \pm 0.44$ & $10 \pm 0.27$ & $11 \pm 0.27$ & $13 \pm 0.46$ & $14 \pm 0.61$ \\
\hline 6 & Serratia marcescens (ATCC 27137) & $17 \pm 0.32$ & $10 \pm 0.40$ & $12 \pm 0.17$ & $13 \pm 0.43$ & $15 \pm 0.58$ \\
\hline 7 & Salmonella typhi (ATCC 13311) & $18 \pm 0.22$ & $12 \pm 0.59$ & $13 \pm 0.45$ & $14 \pm 0.64$ & $16 \pm 0.66$ \\
\hline 8 & Enterococcus faecalis (ATCC 29212) & $15 \pm 0.47$ & $11 \pm 0.20$ & $13 \pm 0.61$ & $15 \pm 0.55$ & $15 \pm 0.13$ \\
\hline 9 & Staphylococcus aureus (ATCC 259323) & $20 \pm 0.50$ & $10 \pm 0.55$ & $12 \pm 0.39$ & $14 \pm 0.17$ & $15 \pm 0.79$ \\
\hline
\end{tabular}

Table 3: Antibacterial activity of iron nanoparticles against 9 reference bacterial strains.

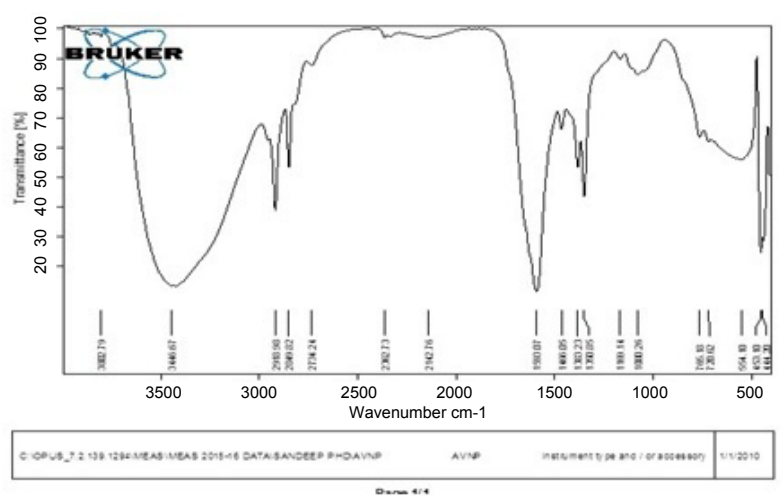

(a)

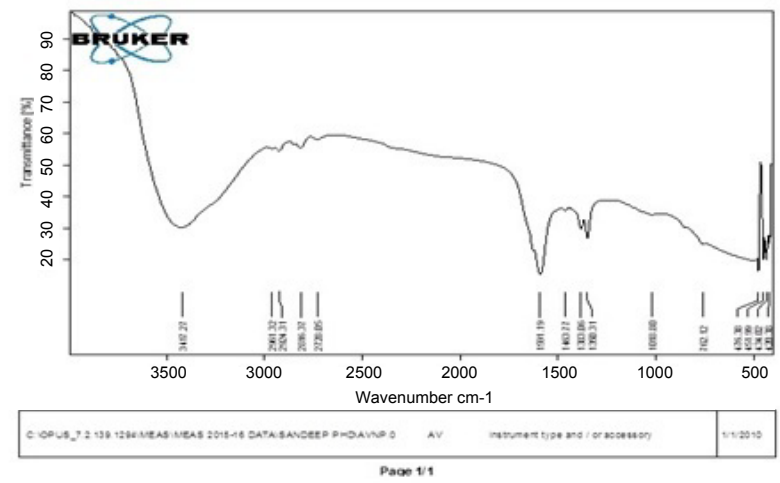

(b)

Figure 3: (a) Absorption spectra of AgNPs formed from FTIR analysis. (b) Absorption spectra of FeNPs formed from FTIR analysis. 


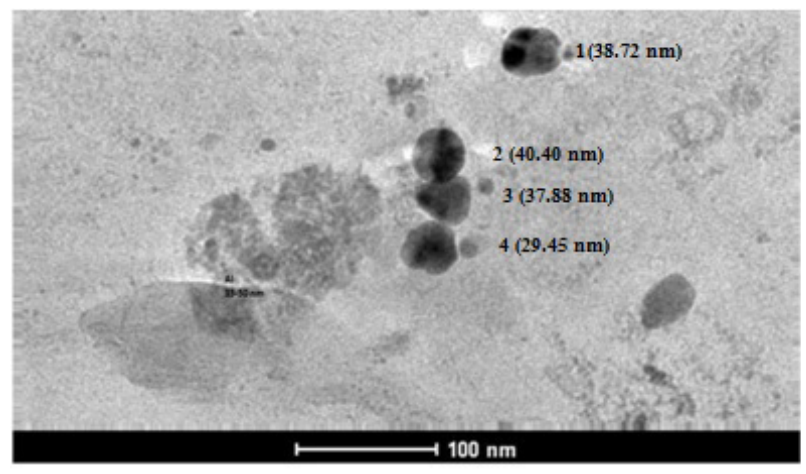

(a)

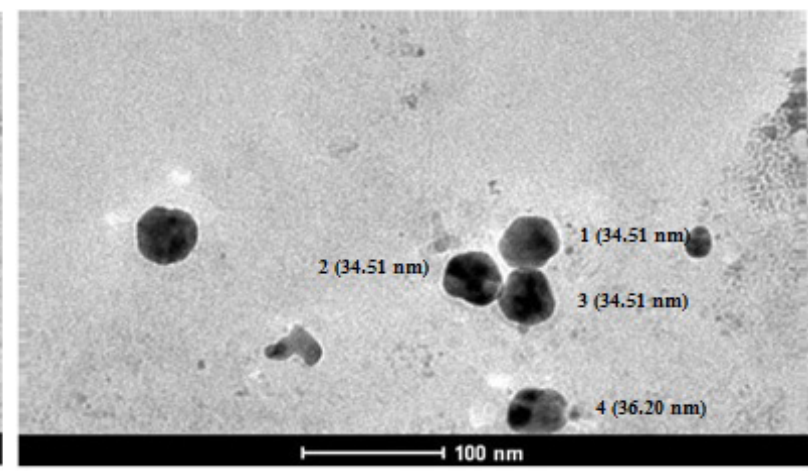

(b)

Figure 4: (a) TEM analysis of synthesized AgNPs nanoparticles. (b) TEM analysis of synthesized FeNPs nanoparticles.

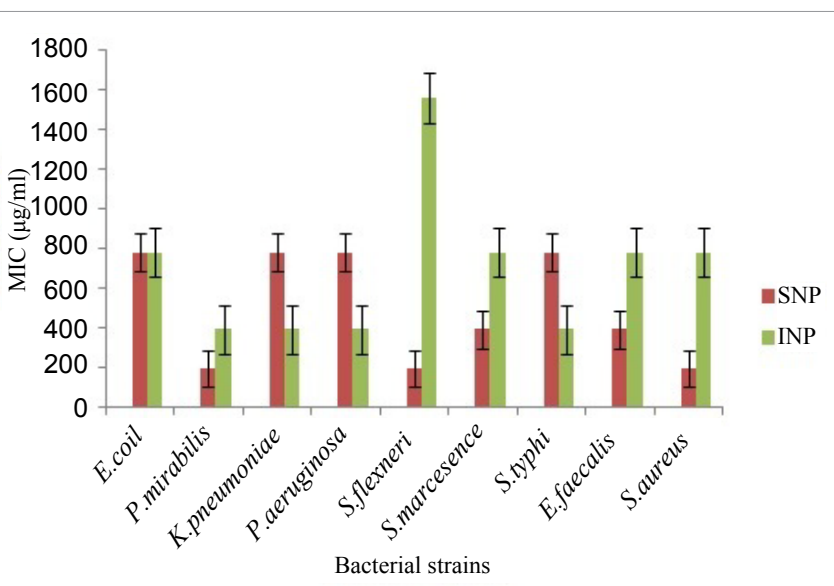

Figure 5: Comparative MIC values $(\mu \mathrm{g} / \mathrm{ml})$ of silver and iron nanoparticles against 9 reference bacterial strains.

by using plant extracts. The main mechanism considered for the process is plant-assisted reduction due to phytochemicals. The main phytochemicals involved are terpenoids, flavones, ketones, aldehydes, amides, and carboxylic acids. Flavones, organic acids, and quinones are water soluble phytochemicals that are responsible for the immediate reduction of the ions [32]. The bioreduction of metal NPs by combinations of biomolecules found in plant extracts such as enzymes, proteins, amino acids, vitamins, polysaccharides, typically obtained by contact of a broth of plant with metal salts, has been intensively investigated [33].

Various plants have been successfully used for the synthesis of biogenic metal nanoparticles. Nanoparticles are synthesized using plant materials such as, Mucuna pruriens [34], Cassia occidentalis [35], Terminalia arjuna [36] Azadirachta indica [37], Tinospora cordifolia [38], Emblica officinalis [39], Capsicum annuum [40], Gliricidia sepium Jacq. [41], Carica papaya [42], Opuntia ficusindica [43], Murraya koenigii [44], Ocimum sanctum [45] and Saururus chinensis [46]. The phytochemicals derived from plant products serve as a prototype to develop less toxic and more effective medicines for controlling the growth of microorganisms [47]. These compounds have significant therapeutic application against different human pathogens. Numerous studies have been conducted with the extracts of various plants for screening of antimicrobial activity in search of new antimicrobial compounds [48]. However, there are various theories suggested about the action of NPs on microbes to cause the antimicrobial effect. They have ability to anchor to the bacterial cell wall and subsequently penetrate it, thereby causing structural changes in the cell membrane like the permeability of cell membrane and death of the cell. There is formation of 'pits' on the cell surface where accumulation of the nanoparticles takes place [49]. The formation of free radicals by NPs may be considered to be another mechanism by which the cells die [50,51].

The extract of the Aloe vera plant has been successfully used to synthesize single crystalline triangular gold nanoparticles (50-350 $\mathrm{nm}$ in size) and spherical silver nanoparticles (15 $\mathrm{nm}$ in size) in high yields by the reaction of aqueous metal source ions (chloroaurate ions for $\mathrm{Au}$ and silver ions for $\mathrm{Ag}$ ) with the extract of the Aloe vera plant [52]. The presence of aloin, emodin, flavonoids and tannins has proved Aloe vera to have anti-bacterial activity [53-55]. Thus the present study highlights the utility of silver and iron nanoparticles synthesized from Aloe vera aqueous extract. Their stability without the addition of any chemical compounds can be used as an excellent source for biosynthesis for the silver and iron nanoparticles in aqueous solution. The reduction of the metal ions through leaf extracts lead to the formation of nanoparticles of fairly well-defined dimensions. The spectroscopic characterizations using UV-Vis analysis were useful in proving the formation of nanoparticles. FTIR analysis in present study showed presence of various medicinally important phytoconstituents on the basis of different functional groups (with their bond types). TEM analysis described the shape and size of synthesized silver and iron nanoparticles.

In present study the green synthesis methods of nanoparticle biosynthesis represents an easy, eco-friendly and cost effective process to prepare NPs by reduction of silver nitrate and ferric chloride solutions with Aloe vera extract. Biosynthesis using Aloe vera extract have smooth way in production of less toxic miniature nanoparticles. The concentration of leaf extract and metal ions played an important role in $\mathrm{Ag}$ and $\mathrm{Fe}$ nanoparticles synthesis. Higher inhibitory activities of silver and iron nanoparticles at higher concentrations of nanoparticles may be due to interact with cytoplasmic components and nucleic acids. Inhibition zones and MIC values of silver and iron NPs against different bacterial strains showed that silver nanoparticles were more effective against $P$. mirabilis, $S$. flexneri and $S$. aureus strains while iron NPs were against $P$. mirabilis, K. pneumonia, P. aeruginosa and S. typhi strains. Against E. coli both silver and iron NPs showed almost similar response. Present findings also concluded that the silver nanoparticles have higher antibacterial potential as compared to iron nanoparticles. 
Citation: Yadav JP, Kumar S, Budhwar L, Yadav A, Yadav M (2016) Characterization and Antibacterial Activity of Synthesized Silver and Iron Nanoparticles using Aloe vera. J Nanomed Nanotechnol 7: 384. doi:10.4172/2157-7439.1000384

The key to their significant bactericidal activity is the ability of silver nanoparticles to release silver ions more specifically. The high specific surface-to-volume ratio of silver nanoparticles increases their contact with microorganisms, likely to be promoting the dissolution of silver ions, thereby improving biocidal effectiveness [56]. Previous studies on antimicrobial potential of different medicinal plant extracts also support our results and efficacy of silver NPs [57,58]

As being non-toxic and environment friendly, the green route of nanoparticle biosynthesis from plants proving their dominance on conventional methods for medicinal importance. A simple, cost effective synthesis of silver and iron NPs using the Aloe vera aqueous extracts is reported in the present study. Main significance of the present work is no involvement of any surfactant, catalyst or template throughout the study.

\section{Conclusion}

Biosynthesis of silver and iron nanoparticles was carried out by using the aqueous extracts of Aloe vera and tested for their antibacterial activity. Comparatively silver nanoparticles of Aloe vera have shown good antibacterial potential than iron nanoparticles against wide range of microbes. Applications of such eco-friendly nanoparticles in bactericidal, wound healing and other medical fields makes this method potentially exciting for large-scale synthesis of silver and iron nanoparticles from Aloe vera.

\section{Competing Interests}

The authors declare that they have no competing interests.

\section{Acknowledgement}

Financial Assistance from UGC, New Delhi in the form of UGC-SAP grant (No. F.3-20/2012, SAP II) and UGC-BSR fellowship is gratefully acknowledged.

\section{Authors' Contributions}

Sandeep Kumar: Collection, acquisition of data, analysis and drafting of the manuscript. Lalita Budhwar: Conception, design and interpretation of data. Amita Yadav: Significant involvement in the interpretation of data and revising the manuscript. Manila Yadav: Participated in the design of the study and performed the statistical analysis. Jaya Parkash Yadav: Design the experiment, guided the students and prepare the final draft of the manuscript.

\section{References}

1. Mahesh B, Satish S (2008) Antimicrobial activity of some important medicinal plant against plant and human pathogens. World J Agric Sci 4: 839-843.

2. Sofowara $A$ (1982) Medicinal plants and antimicrobial activity. J Ethnopharmaco 100: 80-84.

3. Hill RJ (1989) Implications of Monin- Obukhov similarity theory for scalar quantities. J Atmos Sci 46: 2236-2244.

4. Gupta RK, Kesari AN, Murthy PS, Chandra R, Tandon V, et al. (2005) Hypoglycemic and antidiabetic effect of ethanolic extract of leaves of Annona squamosa L. in experimental animals. J Ethnopharmacol 99: 75-81.

5. Sandhu DS, Heinrich M (2005) The use of health foods, spices and other botanicals in the Sikh community in London. Phytother Res 19: 633-642.

6. Steenkamp V, Stewart MJ (2007) Medicinal applications and toxicological activities of Aloe products. Pharm Biol 45: 411-420.

7. Park YI, Jo TH (2006) Perspective of industrial application of Aloe vera. In: Park YI and Lee SK editors. New Perspective on Aloe. Springer Verlag: New York, USA 191-200.

8. Afzal M, Ali M, Hassan RA, Sweedan N, Dhami MS (1991) Identification of Some Prostanoids in Aloe vera Extracts. Planta Med 57: 38-40.

9. Ramamoorthy L, Tizard IR (1998) Induction of apoptosis in a macrophage cell line RAW 264.7 by acemannan, a beta- $(1,4)$-acetylated mannan. Mol Pharmacol 53: 415-421.

10. Tizard ID, Busbee B, Maxwell, Mc K (1994) Effect of acemannan, a complex carbohydrate, on wound healing in young and aged rats. Wounds 6: 201-209.
11. Kahlon JB, Kemp MC, Yawei N, Carpenter RH, Shannon WM, et al. (1991) In vitro evaluation of the synergistic antiviral effects of acemannan in combination with azidothymidine and acyclovir. Mol Biother 3: 214-223.

12. Kawai K, Beppu H, Simpo K, Chihara T, Yamamoto N, et al. (1998) In vivo effects of Aloe arborescens Miller var. natalensis Berger (Kidachi aloe) on experimental Tinea pedis in guinea-pig feet. Phytother Res 12: 178-182.

13. Kumar S, Budhwar L, Yadav A, Yadav M, Yadav JP (2016) Phytochemical screening and antibacterial activity of Aloe vera collected from different climatic regions of India. Nat Prod J 6: 73-82.

14. Heggie S, Bryant GP, Tripcony L, Keller J, Rose P, et al. (2002) A Phase III study on the efficacy of topical Aloe vera gel on irradiated breast tissue. Cancer Nurs 25: 442-451.

15. Sun $Y$, Yin $Y$, Mayers BT, Herricks T, Xia $Y$ (2002) Uniform form silver nanowires synthesis by reducing AgNO3 with ethylene glycol in presence of seeds and poly (vinyl pyrrolidone). Chem Mater 14: 4736-4745.

16. Bankar A, Joshi B, Kumar AR, Zinjarde S (2010) Banana peel extract mediated novel route for the synthesis of silver nanoparticles, Colloids Surf. A Physicochem Eng Asp 368: 58-63.

17. Kasthuri J, Kanthiravan K, Rajendiran N (2008) Phyllanthin-assisted biosynthesis of silver and gold nanoparticles: a novel biological approach. $J$ Nanoparticle Res 15: 1075-1085.

18. Song JY, Kim BS (2009) Rapid biological synthesis of silver nanoparticles using plant leaf extracts. Bioproc Biosyst Eng 32: 79-84.

19. Ingale AG, Chaudhari AN (2013) Biogenic synthesis of nanoparticles and potential applications: an eco-friendly approach. J Nanomed Nanotechol 4: 165.

20. Daniel MC, Astruc D (2004) Gold nanoparticles: assembly, supramolecula chemistry, quantum-size-related properties, and applications toward biology, catalysis, and nanotechnology. Chem Rev 104: 293-346.

21. Okada S, Miyamoto $Y$, Saito M (2001) Three-dimensional crystalline carbon: stable polymers of C20 fullerene. Phys Rev B 64:1-2.

22. Qian L, Yang X (2008) Dendrimers as "controllers" for modulation of electrodeposited silver nanostructures. Colloids Surf A Physicochem Eng Asp 317: 528-534.

23. Yakes MK, Cress CD, Tischler JG, Bracker AS (2010) Three-dimensional control of self-assembled quantum dot configurations. ACS Nano 4: 3877-3882.

24. Sarker SD, Nahar L, Kumarasamy Y (2007) Microtitre plate-based antibacteria assay incorporating resazurin as an indicator of cell growth, and its application in the in vitro antibacterial screening of phytochemicals. Methods 42: 321-324.

25. Sadiq MB, Hanpithakpong W, Tarning J, Anal AK (2015) Screening of phytochemicals and In vitro evaluation of antibacterial and antioxidant activities of leaves, pods and bark extracts of Acacia nilotica (L.) Del Ind Crops Prod 77: 873-882.

26. D'Angelo JA, Zodrow EL (2011) Chemometric study of functional groups in different layers of Trigonocarpus grandis ovules (Pennsylvanian seed fern, Canada). Org Geochem 42: 1039-1054.

27. Bhattacharya D, Gupta RK (2005) Nanotechnology and potential of microorganisms. Crit Rev Biotechnol 25: 199-204.

28. Mohanpuria P, Rana NK, Yadav SK (2008) Biosynthesis of nanoparticles: technological concepts and future applications. J Nanopart Res 10(3): 507-17.

29. Gericke M, Pinches A. (2006) Biological synthesis of metal nanoparticles Hydrometallurgy 83: 132-140.

30. Harris AT, Bali R (2008) On the formation and extent of uptake of silver nanoparticles by live plants. J Nanopart Res 10: 691-695.

31. Farooqui MDA, Chauhan PS, Krishnamoorthy P, Shaik J (2010) Extraction of silver nanoparticles from the leaf extracts of Clerodendrum inerme. Dig J Nanomater Biostruct 5(1): 43-49.

32. Prabhu S, Poulose E (2012) Silver nanoparticles: mechanism of antimicrobia action, synthesis, medical applications, and toxicity effects. Int Nano Lett 2: 32.

33. Iravani R (2011) Green synthesis of metal nanoparticles using plants. Green Chem 13: 2638-2650.

34. Arulkumar S, Sabesan M (2010) Biosynthesis and characterization of gold nanoparticle using antiparkinsonian drug Mucuna pruriens plant extract. Int J Res Pharma Sci 1(4): 417-420. 
Citation: Yadav JP, Kumar S, Budhwar L, Yadav A, Yadav M (2016) Characterization and Antibacterial Activity of Synthesized Silver and Iron Nanoparticles using Aloe vera. J Nanomed Nanotechnol 7: 384. doi:10.4172/2157-7439.1000384

35. Arya V, Yadav S, Kumar S, Yadav JP (2010) Antimicrobial activity of Cassia occidentalis L, (leaf) against various human pathogenic microbes. Life Sci Medi Res 9: 1-11.

36. Ahmed S, SIkram S (2015) Silver nanoparticles: One pot green synthesis using Terminalia arjuna extract for biological application. J Nanomed Nanotechnol 6. 309 .

37. Shankar SS, Rai A, Ahmad A, Sastry MJ (2004) Rapid synthesis of Au, Ag, and bimetallic Au core-Ag shell nanoparticles using Neem (Azadirachta indica) leaf broth. J Colloid Interface Sci 275: 496-502.

38. Singh K, Panghal M, Kadyan S, Chaudhary U, Yadav JP (2014) Antibacterial Activity of Synthesized Silver Nanoparticles from Tinospora cordifolia against Multi Drug Resistant Strains of Pseudomonas aeruginosa isolated from burn patients. J Nanomed Nanotechnol 5: 192.

39. Ankamwar B, Damle C, Ahmad A, Sastry M (2005) Biosynthesis of gold and silver nanoparticles using Emblica officinalis fruit extract, their phase transfer and transmetallation in an organic solution. J Nanosci Nanotechnol 5: 1665-1671.

40. Li S, Shen Y, Xie A, Yu X, Qui L, Zhang L, et al. (2007) Green synthesis of silver nanoparticles using Capsicum annuum L. Extract Green Chem 9: 852-858.

41. Raut RW, Lakkakula JR, Kolekar NS, Mendhulkar VD, Kashid SB (2009) Phytosynthesis of silver nanoparticle using Gliricidia sepium (Jacq.). Cur Nanosci 5(1): 117-122.

42. Mude N, Ingle A, Gade A, Rai M (2009) Synthesis of silver nanoparticles using callus extract of Carica papaya- a first report. J Plant Biochem Biot 18(1): 83-86.

43. Gade A, Gaikwad K, Tiwari V, Yadav A, Ingle A, et al. (2010) Biofabrication of silver nanoparticles by Opuntia ficusindica: In vitro antibacterial activity and study of the mechanism involved in the synthesis. Curr Nanosci 6(4): 370-375.

44. Bonde SR, Rathod DP, Ingle AP, Ade RB, Gade AK, et al. (2012) First report of Murraya koenigii mediated synthesis of silver nanoparticles and its activity against three human pathogenic bacteria. Nanosci methods 1: 25-36.

45. Bindhani BK, Panigrahi AK (2015) Biosynthesis and Characterization of silver nanoparticles (SNPs) by using leaf extracts of Ocimum sanctum $L$ (Tulsi) and study of its antibacterial activities. J Nanomed Nanotechnol 6: 008.

46. Nagajyothi PC, Prasad NVKV, Sreekanth TVM, Lee KD (2011) Bio-fabrication of silver nanoparticles using leaf extract of Saururus chinenis. Dig J Nanomater Biostruct 6: 121-133.
47. Ahmad I, Beg AZ (2001) Antimicrobial and phytochemical studies on 45 Indian medicinal plants against multi-drug resistant human pathogens. J Ethnopharmacol 74: 113-123.

48. Sharma A (2011) Antibacterial activity of ethanolic extracts of some arid zone plants. Int J Pharm Tech Res 3: 283-286.

49. Sondi I, Salopek-Sondi B (2004) Silver nanoparticles as antimicrobial agent: a case study on $E$. coli as a model for Gram-negative bacteria. J Colloid Interface Sci 275: 177-182.

50. Danilczuk M, Lund A, Sadlo J, Yamada H, Michalik J (2006) Conduction electron spin resonance of small silver particles. Spectrochim Acta A Mol Biomol Spectrosc 63: 189-191.

51. Kim JS, Kuk E, Yu KN, Kim JH, Park SJ, et al. (2007) Antimicrobial effects of silver nanoparticles. Nanomedicine 3: 95-101.

52. Chandran SP, Chaudhary M, Pasricha R, Ahmad A, Sastry M (2006) Synthesis of gold nanotriangles and silver nanoparticles using Aloe vera plant extract Biotechnol Prog 22: 577-583.

53. Kumar S, Yadav JP (2014) Ethnobotanical and pharmacological properties of Aloe vera: A review. J Med Plant Res 8: 1387-1398.

54. Ramasubramanian TS, Sivakumar VT, Thirumalai AV (2010) Antimicrobia activity of Aloe vera (L.) Burm. f. against pathogenic microorganisms. J Bio Sci Res 4: 251-8.

55. Arunkumar S, Muthuselvam M (2009). Analysis of phytochemical constituents and antimicrobial activities of Aloe vera $\mathrm{L}$. against clinical pathogens. World $\mathrm{J}$ Agric Sci 5: 572- 576.

56. Nithya R, Ragunathan R (2009) Synthesis of silver nanoparticles using Pleurotus sajor caju and its antimicrobial study. Dig J Nanomater Biostruct 4: 623-629.

57. Singh K, Panghal M, Kadyan S, Yadav JP (2014) Evaluation of antimicrobia activity of synthesized silver nanoparticles using Phyllanthus amarus and Tinospora cordifolia medicinal plants. J Nanomed Nanotechnol 5: 250.

58. Tran QH, Le AT (2013) Silver nanoparticles: synthesis, properties, toxicology applications and perspectives. Adv Nat Sci: Nanosci Nanotechnol 4(3): 33001 